\title{
APLIKASI CRUDE ENZIM SELULASE DARI TONGKOL JAGUNG (Zea mays L) PADA PRODUKSI ETANOL DENGAN METODE SIMULTANEOUS SACCHARIFICATION AND FERMENTATION (SSF)
}

\author{
Ery Susiany Retnoningtyas*), Antaresti, dan Aylianawati \\ Laboratorium Teknologi Bioproses, Jurusan Teknik Kimia, \\ Fakultas Teknik, Universitas Katolik Widya Mandala Surabaya \\ Jl. Kalijudan 37 Surabaya 60114, Indonesia, Telp: (031)3893933, Faks: (031)3891267 \\ ${ }^{*}$ Penulis Korespondensi: ery.srt@gmail.com
}

\begin{abstract}
APPLICATION OF CRUDE CELLULASE ENZYMES FROM CORN COB (Zea mays L) IN ETHANOL PRODUCTION BY SIMULTANEOUS SACCHARIFICATION AND FERMENTATION METHOD (SSF). Abundant corn cobs as a by-product from the processing of corn industry, provides an opportunity to be used as a substrate in the production of crude cellulase enzymes. Crude cellulase enzymes from corn cobs later applied to the production of ethanol by simultaneous saccharification and fermentation (SSF) using corn cob as raw material. The purpose of this research is to study the effect of crude cellulase enzymes volume, the performance of crude cellulase enzymes in producing ethanol and compare its performance with crude commercial enzymes. The research was composed of two phases, namely pretreatment of corn cobs, and fermentation. Dried corn cobs were grinded to powder having size of 12 mesh, and treated with steam explosion for 60 minutes. For the fermentation process, nutrients, crude cellulase enzymes and cultures of Saccharomyces cerevisiae was added to the pretreated powder. The fermentation was carried out at $30^{\circ} \mathrm{C}$ for 120 hours, while the observations were made every 24 hours. The results showed that ethanol produced using crude cellulase enzymes and crude commercial enzymes are $1.28 \%$ and $2.89 \%$ respectively.
\end{abstract}

Keywords: cellulase; corn cobs; crude enzyme; ethanol; saccharomyces cerevisiae

\begin{abstract}
Abstrak
Tongkol jagung yang melimpah sebagai produk samping dari hasil pengolahan industri jagung pipilan, memberikan peluang untuk dimanfaatkan sebagai substrat dalam produksi crude enzim selulase. Crude enzim selulase dari tongkol jagung selanjutnya diaplikasikan pada produksi etanol dengan memanfaatkan tongkol jagung juga dengan metode simultaneous saccharification and fermentation (SSF). Penelitian ini bertujuan untuk mempelajari pengaruh volume crude enzim selulase terhadap kadar etanol, kinerja crude enzim selulase dalam memproduksi etanol dan membandingkan kinerjanya dengan crude enzim komersial. Penelitian ini terbagi dalam dua tahap yaitu : pretreatment tongkol jagung, dan fermentasi. Tongkol jagung yang sudah dikeringkan, dihaluskan hingga menjadi serbuk dengan ukuran 12 mesh, dan diberi perlakuan hidrolisis dengan uap panas (steam explosion) selama 60 menit. Serbuk tongkol jagung difermentasi,dengan penambahan nutrisi, crude enzim selulase dan jamur Saccharomyces cerevisiae. Proses fermentasi dilakukan pada suhu $30^{\circ} \mathrm{C}$ selama 120 jam, sedangkan pengamatan dilakukan setiap 24 jam. Hasil penelitian menunjukkan produksi etanol yang dihasilkan dengan menggunakan crude enzim selulase dan crude enzim komersial berturut-turut adalah 1,28 dan 2,89\%.
\end{abstract}

Kata kunci: selulase; tongkol jagung; crude enzim; etanol; saccharomyces cerevisiae

\section{PENDAHULUAN}

Sebagai salah satu negara pertanian, Indonesia menghasilkan jagung dalam bentuk pipilan kering.
Menurut data statistik (BPS, 2012), produksi jagung tahun 2011 sebesar 923 ton pipilan kering. Produksi jagung pipilan yang melimpah ini menyisakan tongkol 
jagung sebagai limbah pertanian. Kandungan selulosa yang cukup tinggi dari tongkol jagung (Tabel 1) yaitu 41\% memungkinkan untuk dimanfaatkan sebagai substrat dalam produksi crude enzim selulase. Beberapa fungi dapat menghasilkan enzim selulase seperti : Humicola, Penicillium, Fusarium, Aspergillus dan Trichoderma. Trichoderma ressei adalah fungi yang menghasilkan yield selulase yang tinggi sehingga diproduksi secara komersial (Sukumaran dkk., 2005).

Tabel 1. Komposisi tongkol jagung

\begin{tabular}{lc}
\hline \multicolumn{1}{c}{ Komponen } & Komposisi (\%) \\
\hline Air & 9,6 \\
Abu & 1,5 \\
Hemiselulosa & 36,0 \\
Selulosa & 41,0 \\
Lignin & 6,0 \\
Pektin & 3,0 \\
Pati & 0,014 \\
\hline
\end{tabular}

Sumber : Lorenz dan Kulp (1991)

Penggunaan enzim selulase dalam produksi etanol dari bahan lignoselulosa secara komersial masih cukup mahal (Yanagisawa dkk., 2011). Biaya produksi enzim selulase dapat mencapai 27-40\% dari biaya produksi etanol dari bahan lignoselulosa (Duff dan Murray, 1996). Penggunaan enzim selulase dalam proses hidrolisis bahan lignoselulosa sudah banyak diteliti (Anwar dkk., 2012; Poornejad, dkk., 2013), namun penggunaan crude enzim selulase dalam proses hidrolisis bahan lignoselulosa masih jarang (Mutreja dkk., 2011). Kinerja crude enzim selulase tentunya lebih rendah dibandingkan dengan enzim yang sudah dimurnikan, tetapi biaya produksi yang lebih murah menjadi daya tarik untuk diaplikasikan di industri. Beberapa industri bahkan mulai melakukan inovasi baik di proses maupun di bahan baku untuk menghasilkan enzim yang murah (Zhang dkk., 2006).

Penelitian ini bertujuan untuk mempelajari pengaruh volume crude enzim selulase terhadap produksi etanol dari bahan lignoselulosa (tongkol jagung), kinerja crude enzim selulase dalam memproduksi etanol dan membandingkan kinerjanya dengan crude enzim komersial.

\section{METODE PENELITIAN} Bahan

Tongkol jagung diperoleh dari limbah pasar Gubeng Surabaya. Bahan kimia spesifikasi analysis seperti $\quad \mathrm{KH}_{2} \mathrm{PO}_{4}, \quad \mathrm{M}_{\mathrm{g}} \mathrm{SO}_{4} .7 \mathrm{H}_{2} \mathrm{O}, \quad\left(\mathrm{NH}_{4}\right)_{2} \mathrm{SO}_{4}$, $\left(\mathrm{NH}_{4}\right)_{2} \mathrm{PO}_{4}$, glukosa, Potato Dextrose Agar dari Merck sedangkan yeast extract dari Difco. Crude enzim komersial dari PT. Lautan Luas dengan spesifikasi teknis.

\section{Mikroorganisme}

Mikroba Trichoderma ressei Bio N 579 dan Saccharomyces cerevisiae Bio 370 et diperoleh dari Jurusan Biologi Universitas Airlangga Surabaya. Trichoderma ressei Bio N 579 digunakan untuk pembuatan crude enzim selulase dari tongkol jagung (Carmelita dkk., 2007) sedangkan Saccharomyces cerevisiae Bio 370 et digunakan untuk produksi etanol juga dari tongkol jagung

\section{Preparasi Substrat}

Mula-mula tongkol jagung yang sudah dipotong $\pm 1 \mathrm{~cm}^{3}$ dikeringkan, lalu dihaluskan dan diayak hingga berukuran 12 mesh. Selanjutnya serbuk tongkol jagung diberi perlakuan awal yaitu hidrolisis dengan uap panas (steam explosion) dengan cara dimasukkan ke dalam autoclave suhu $121^{\circ} \mathrm{C}$ tekanan 15 psi selama 60 menit.

\section{Pembuatan Crude Enzim Selulase}

Crude enzim selulase dibuat dengan fermentasi substrat padat. Sebanyak 5 gram serbuk tongkol jagung yang sudah diberi perlakuan awal dan $15 \mathrm{~mL}$ nutrisi dengan komposisi (Asada dkk., 2012) : $\left(\mathrm{NH}_{4}\right)_{2} \mathrm{SO}_{4} 10 \mathrm{~g} / \mathrm{L}, \mathrm{KH}_{2} \mathrm{PO}_{4} 3 \mathrm{~g} / \mathrm{L}$, dan $\mathrm{MgSO}_{4} \cdot 7 \mathrm{H}_{2} \mathrm{O}$ $0,5 \mathrm{~g} / \mathrm{L}$ dimasukkan dalam erlenmeyer $100 \mathrm{ml}$ dan disteril dengan autoclave. Selanjutnya ditambahkan 1 $\mathrm{mL}$ suspensi Trichoderma reesei dengan konsentrasi $1,9 \times 10^{8} \mathrm{sel} / \mathrm{mL}$ dan difermentasikan pada suhu $30^{\circ} \mathrm{C}$ selama 96 jam. Setelah proses fermentasi dilakukan ekstraksi crude enzim selulase yang telah dihasilkan dengan menggunakan $40 \mathrm{~mL}$ Tween 80 0,01\% dan diuji aktivitasnya setelah crude enzim dipisahkan dari spora Trichoderma reesei.

\section{Fermentasi Etanol}

Etanol dibuat dengan proses Simultaneous Sacharification and Fermentation (SSF). Satu gram tongkol jagung berukuran 12 mesh dalam erlenmeyer $100 \mathrm{~mL}$ yang sudah mengalami perlakuan awal hidrolisis dengan uap panas, dicampur dengan $10 \mathrm{~mL}$ nutrisi, $10 \mathrm{~mL}$ inokulum yeast Saccharomyces cerevisiae dengan konsentrasi $6,4 \times 10^{6} \mathrm{sel} / \mathrm{mL}$ dan beberapa variasi penambahan volume crude enzim. Komposisi nutrisi yang ditambahkan adalah $\left(\mathrm{NH}_{4}\right)_{2} \mathrm{PO}_{4} 1 \mathrm{~g} / \mathrm{L}, \mathrm{MgSO}_{4} .7 \mathrm{H}_{2} \mathrm{O}$ 0,05 g/L dan yeast extract $2 \mathrm{~g} / \mathrm{L}$ sedangkan komposisi di inokulum yeast adalah glukosa $10 \mathrm{~g} / \mathrm{L}, \quad \mathrm{KH}_{2} \mathrm{PO}_{4} \quad 0,1 \mathrm{~g} / \mathrm{L}$, $\mathrm{MgSO}_{4} \cdot 7 \mathrm{H}_{2} \mathrm{O} 0,1 \mathrm{~g} / \mathrm{L},\left(\mathrm{NH}_{4}\right)_{2} \mathrm{SO}_{4} 0,1 \mathrm{~g} / \mathrm{L}$ dan yeast extract $1 \mathrm{~g} / \mathrm{L}$ (Asada dkk., 2012). Fermentasi dilakukan pada suhu $30^{\circ} \mathrm{C}$ selama 120 jam. Tiap 24 jam dilakukan pengambilan sampel untuk dianalisa gula reduksi dan etanol.

\section{Analisa}

Tongkol jagung yang sudah mengalami pengecilan ukuran dan dihidrolisis dengan uap panas (steam explosion), dianalisa kadar air, abu, selulosa, pektin dan protein (Sudarmadji, 1997). Pengukuran aktivitas crude enzim selulase menggunakan metode CMC-ase dan FP-ase (Lee, 1992). Penentuan konsentrasi gula reduksi menggunakan metode dinitrosalicylic acid (Lee, 1992) dan diukur dengan spektrofotometer UV-Vis pada panjang gelombang 510 nm. Kadar etanol dianalisa dengan metode 
dichromate (Anwar dkk., 2012) dan diukur dengan spektrofotometer UV-Vis pada panjang gelombang $583 \mathrm{~nm}$.

\section{HASIL DAN PEMBAHASAN}

\section{Karakterisasi Tongkol Jagung}

Tongkol jagung diberi perlakuan awal (pretreatment) sebelum digunakan sebagai substrat dalam proses fermentasi oleh mikroorganisme. Sebagai bahan lignoselulosa, komponen lignin dalam tongkol jagung harus dihilangkan atau dikurangi agar selulosa dapat didedgradasi dengan mudah oleh mikroba. Perlakuan pengecilan ukuran dan hidrolisis dengan uap panas (steam explosion) cukup efisien dalam proses delignification bahan lignoselulosa (Mutreja dkk., 2011). Hasil analisa terhadap tongkol jagung yang sudah diberi perlakuan hidrolisis dengan uap panas (steam explosion) dapat dilihat pada Tabel 2.

Tabel 2. Komposisi tongkol jagung setelah

\begin{tabular}{lc}
\multicolumn{2}{c}{ pretreatment } \\
\hline \multicolumn{1}{c}{ Komponen } & Komposisi (\%) \\
\hline Air & 8,55 \\
Abu & 2,41 \\
$\alpha-$ selulosa & 34,41 \\
Pektin & 3,90 \\
Protein & 2,25 \\
\hline
\end{tabular}

Tabel 2 menunjukkan kandungan selulosa yang cukup tinggi $(34,41 \%)$ pada tongkol jagung. Sebelum dimanfaatkan oleh Saccharomyces cerevisiae, selulosa ini akan dihidrolisis dahulu oleh enzim selulase menjadi selobiosa dan dihidrolisis lebih lanjut menjadi glukosa.

\section{Pengaruh Penambahan Volume Crude Enzim Selulase}

Pada penelitian ini tongkol jagung digunakan untuk memproduksi crude enzim selulase dari Trichoderma ressei dengan aktivitas yang dihasilkan : CMC-ase 0,074 IU/mL dan FP-ase 0,024 IU/mL. Crude enzim selulase ini selanjutnya digunakan dalam proses fermentasi etanol dari tongkol jagung. Hasil penelitian dengan beberapa variasi volume crude enzim selulase dalam proses fermentasi etanol dengan metode Simultaneous Sacharification and Fermentation (SSF) dapat dilihat pada Gambar 1.

Berdasarkan Gambar 1 tersebut, maka volume crude enzim selulase yang memberikan hasil kadar etanol tinggi adalah $10 \mathrm{~mL}$. Hal ini mengindikasikan bahwa proses hidrolisis selulosa dari tongkol jagung oleh crude enzim selulase menghasilkan jumlah glukosa yang sebanding dengan glukosa yang dimanfaatkan oleh Saccharomyces cereviseae untuk diubah menjadi produk etanol.

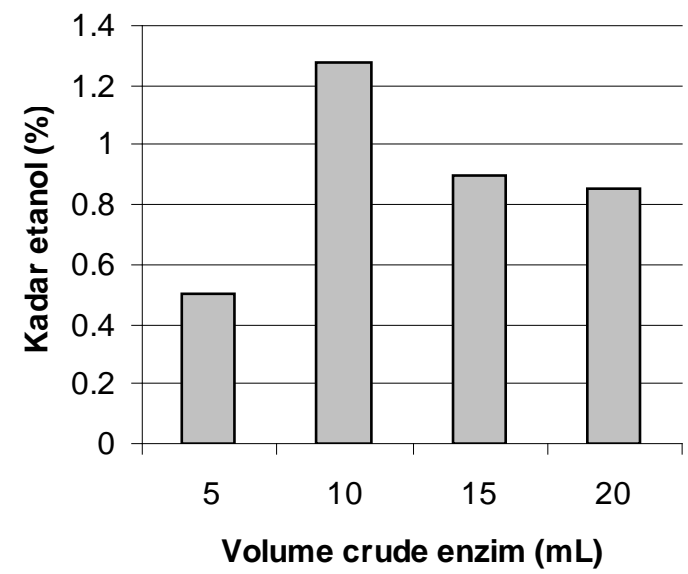

Gambar 1. Kadar etanol yang dihasilkan pada beberapa variasi volume crude enzim selulase pada proses fermentasi etanol dengan metode Simultaneous Sacharification and Fermentation (SSF)

Pada penambahan crude enzim selulase $15 \mathrm{~mL}$ dan $20 \mathrm{~mL}$ tidak menambah kemampuan hidrolisis selulosa, hal ini dapat dijelaskan sebagai berikut : semakin banyak crude enzim selulase maka sisi aktif enzim yang berkontak dengan substrat dalam hal ini selulosa juga bertambah banyak akibatnya makin banyak selulosa yang dihidrolisis menjadi glukosa, tetapi glukosa yang terlalu banyak menyebabkan inhibisi produk glukosa karena glukosa ini akan menempel pada sisi aktif enzim sehingga luas permukaan kontak enzim dengan substrat selulosa menjadi lebih sedikit (Roukas, 1996).

\section{Perbandingan Kinerja Crude Enzim Selulase Dengan Enzim Komersial}

Pertumbuhan Saccharomyces cerevisiae pada substrat tongkol jagung dapat diidentifikasi dari berkurangnya glukosa (gula reduksi) dan terbentuknya produk etanol.

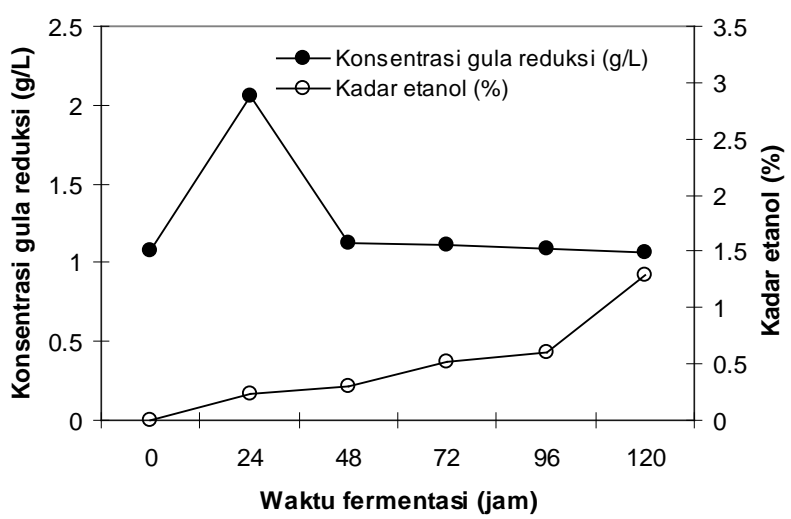

Gambar 2. Kinerja crude enzim selulase dari tongkol jagung dalam menghasilkan etanol 
Gambar 2 menunjukkan kinerja crude enzim selulase dari tongkol jagung dengan aktivitas CMCase $0,074 \mathrm{IU} / \mathrm{mL}$ dan FP-ase 0,024IU/ml. Gambar 2 tersebut juga dapat diketahui bahwa pada 0-24 jam terjadi peningkatan konsentrasi gula reduksi yang signifikan dari 1,0720 g/L menjadi 2,0558 g/L yaitu sebesar 0,9838 g/L keadaan ini menunjukkan terjadi hidrolisis oleh crude enzim selulase. Enzim ini menghidrolisa selulosa menjadi selobiosa dan menghidrolisanya lebih lanjut menjadi glukosa. Setelah 24 jam Saccharomyces cerevisiae mengkonsumsi glukosa, hal ini ditandai dengan terjadinya penurunan konsentrasi gula reduksi yang signifikan dari 2,06 g/L menjadi 1,12 g/L yaitu sebesar $0,9358 \mathrm{~g} / \mathrm{L}$. Tetapi setelah 48 jam konsumsi gula reduksi cenderung konstan, hal ini mengindikasikan bahwa Saccharomyces cerevisiae telah memasuki fase stasioner. Setelah waktu 48 jam hingga 120 jam, terjadi peningkatan produksi etanol yang signifikan yaitu 0,98\%. Menurut Mutreja dkk. (2011), produksi etanol mencapai maksimum pada saat mikroorganisme berada di fase stasioner.

Kinerja crude enzim komersial dalam menghasilkan etanol disajikan pada Gambar 3.

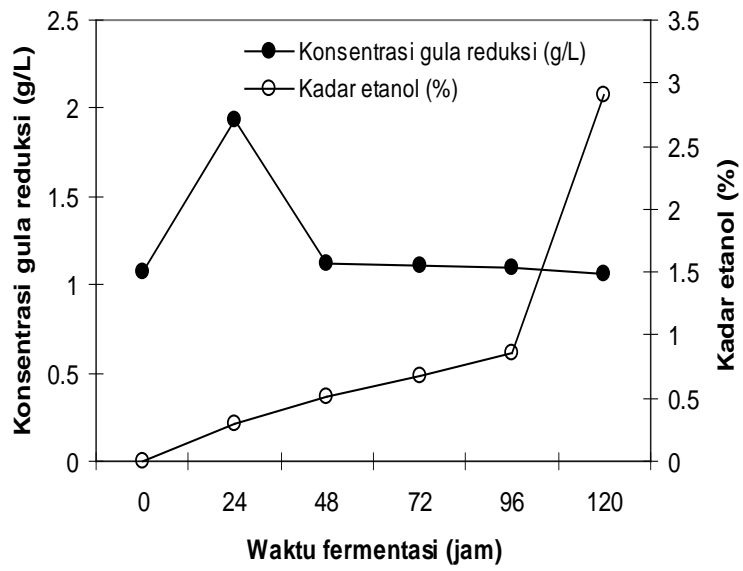

Gambar 3. Kinerja crude enzim komersial dalam menghasilkan etanol

Aktivitas dari enzim ini dapat dilihat pada waktu fermentasi 0-24 jam, saat terjadi peningkatan konsentrasi gula reduksi yang signifikan (0,8589 g/L). Hal ini mengindikasikan bahwa enzim dapat menghidrolisa selulosa hingga menjadi glukosa (gula reduksi) yang siap dikonsumsi oleh Saccharomyces cerevisiae yaitu saat 24-48 jam, tetapi setelah 48 jam konsumsi gula reduksi mulai menurun bahkan cenderung konstan. Pada saat konsentrasi gula reduksi cenderung konstan, kadar etanol mengalami peningkatan yang signifikan (2,381\%).

Gambar 2 maupun 3 menunjukkan bahwa pembentukan produk etanol terjadi pada saat pertumbuhan Saccharomyces cerevisiae yang berarti termasuk growth-associated products (Shuler dan Kargi, 1992). Jadi pada fase adaptasi, Saccharomyces cerevisiae sudah menghasilkan etanol dengan memanfaatkan glukosa dari media awal. Setelah memasuki fase eksponensial hingga stasioner, mikroba memanfaatkan glukosa hasil hidrolisa selulosa.

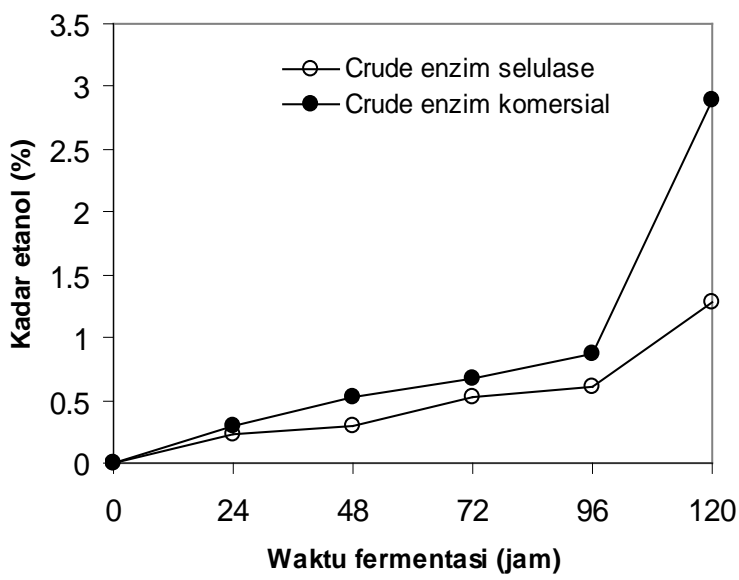

Gambar 4. Perbandingan kinerja crude enzim dalam menghasilkan etanol

Gambar 4 menunjukkan bahwa kemampuan crude enzim komersial dalam menghidrolisa selulosa lebih baik dibandingkan crude enzim selulase dari tongkol jagung sehingga dihasilkan kadar etanol yang tinggi (2,89\%). Tetapi crude enzim selulase maupun crude enzim komersial menunjukkan peningkatan kadar etanol yang signifikan setelah 96 jam. Kemampuan crude enzim selulase ini dalam menghasilkan etanol 0,4 kali lebih rendah dari crude enzim komersial. Hal ini disebabkan penurunan gula reduksi setelah 48 jam hingga 120 jam pada crude enzim selulase lebih kecil $(0,0537 \mathrm{~g} / \mathrm{L})$ daripada crude enzim komersial $(0,0613 \mathrm{~g} / \mathrm{L})$. Berkurangnya gula reduksi ini mengindikasikan adanya etanol yang terbentuk (Xin, 2013). Semakin rendah penurunan gula reduksi maka etanol yang dihasilkan juga lebih rendah.

\section{KESIMPULAN}

Crude enzim selulase dari tongkol jagung dapat digunakan untuk menghidrolisa tongkol jagung secara simultan dengan proses fermentasi dibantu Saccharomyces cerevisiae. Tetapi kinerja dari crude enzim ini masih lebih rendah dibandingkan crude enzim komersial dalam menghasilkan etanol. Crude enzim selulase dari tongkol jagung menghasilkan etanol 1,28\% sedangkan crude enzim komersial dapat menghasilkan etanol 2,89\% pada aktivitas enzim yang sama.

\section{UCAPAN TERIMA KASIH}

Penelitian ini dibiayai oleh Kopertis Wilayah VII Jawa Timur, Kementrian Pendidikan Nasional, sesuai dengan Surat Perjanjian Pelaksanaan Hibah Penelitian Nomor : 0006/SP2H/PP/K7/KL/II/2012, tanggal 9 Pebruari 2012. 


\section{DAFTAR PUSTAKA}

Anwar, Z., Gulfraz, M., Asad, M.J., Imran, M., Akram, Z., Mehmood, S., Rehman, A., Anwar, P., and Sadiq, A., (2012), Bioethanol Productions from Rice Polish by Optimization of Dilute Acid Pretreatment and Enzymatic Hydrolysis, African Journal of Biotechnology, 11(4), pp. 992-998.

Asada, C., Sasaki, C., Uto, Y., Sakafuji, J., and Nakamura, Y., (2012), Effect of Steam Explosion Pretreatment with Ultra-high Temperature and Pressure on Effective Utilization of Softwood Biomass, Biochemical Engineering Journal, 60, pp. 25-29.

BPS, (2012), Berita Resmi Statistik: Produksi Padi, Jagung dan Kedelai, No. 47/07/21/Th.VI, 02 Juli 2012.

Carmelita, S., Sugiarto, E., Aylianawati, dan Retnoningtyas, E.S., (2007), Pembuatan Enzim Selulase dari Tongkol Jagung Menggunakan Trichoderma ressei, Prosiding Seminar Nasional Teknik Kimia, Bandung, pp. A16-A20.

Duff, S.J.B. and Murray, W.D., (1996), Bioconversion of Forest Products Industry Waste Cellulosics to Fuel Ethanol : A Review, Bioresource Technology, 55 (1), pp. 1-33.

Lee, J.M., (1992), Biochemical Engineering, PrenticeHall, New Jersey, pp. 94-95.

Lorenz, K.J. and Kulp, K., (1991), Handbook of Cereal Science and Technology, Marcel Dekker, New York.

Mutreja, R., Das, D., Goyal, D., and Goyal, A., (2011), Bioconversion of Agricultural Waste to Ethanol by SSF Using Recombinant Cellulase from
Clostridium thermocellum, Enzyme Research, Vol. 2011, Article ID 340279, pp. 1-6.

Poornejad, N., Karimi, K., and Behzad, T., (2013), Improvement of Saccharification and Ethanol Production From Rice Straw by NMMO and [BMIM][OAc] Pretreatments, Industrial Crops and Products, 41, pp. 408-413.

Roukas, T., (1996), Continuous Bioetanol Production from Nonsterilized Carob Pod Extract by Immobilized Saccharomyces cerevisiae on Mineral Kissiris Using A Two Reactor System, Applied Biochemistry and Biotechnology, 59 (3), pp.299-307.

Shuler, M.L. and Kargi, F., (1992), Bioprocess Engineering : Basic Concepts, Prentice-Hall, New Jersey, pp.159-161.

Sudarmadji, S., Haryono, B., dan Suhardi, (1997), Prosedur Analisa untuk Bahan Makanan dan Pertanian, Edisi 4, Liberty, Yogyakarta

Sukumaran, R.K., Singhania, R.R., and Pandey, A., (2005), Microbial Cellulases-Production, Application and Challenges, Journal of Scientific \& Industrial Research, 64, pp. 832-844.

Xin, F., Zhang, H., and Wong, W., (2013), Bioethanol Production from Horticultural Waste Using Crude Fungal Enzyme Mixtures Produced by Solid State Fermentation, Bioenerg. Res., 6, pp. 1030-1037

Yanagisawa, M., Ojima, T., and Nakasaki, K., (2011), Bioethanol from Sea Lettuce with The Use of Crude Enzymes Derived from Waste, Jornal of Material Cycles and Waste Management, 13, pp. 321-326.

Zhang, Y.H.P., Himmel, M.E., and Mielenz, J.R., (2006), Outlook for Cellulase Improvement : Screening and Selection Strategies, Biotechnology Advances, 24, pp. 452-481. 